\title{
Towards a Sustainable Future: Promoting Sustainability, Sustainability Accounting and Reporting among Future Professional Accountants
}

\author{
Dr. Arnold V. Salcedo, CPA, DBM1', Shane S. Salcedo, CPA ${ }^{1}$ \\ ${ }^{1}$ Holy Angel University, Angeles City, Philippines
}

\begin{abstract}
While most of the sustainability studies focused are on areas of engineering and architecture, sustainability accounting and reporting are concepts that need to be introduced among people nowadays, specifically accountancy students, with the belief that the students today, will become the workforce and leaders of tomorrow. The study focused on promoting the various concepts among ninety-six ( $n=96)$ accountancy students who are in their terminal year. The students were subjected to a pre-test \& post-test experimental design group with viewing video presentations on triple bottom-line, sustainability reporting, true cost accounting and a sample of Global Reporting Initiative Report (GRI) as intervention activities, that aimed to provide an overview and a level of understanding on the targeted concepts. Results show a significant difference on the level of awareness before and after the three concepts were introduced. The participants were willing to learn more about sustainability accounting while half of them would consider to enroll in a graduate program that specializes on leadership in a sustainable enterprise along with management courses concentrating on sustainability. As a conclusion, sustainability accounting and reporting in the Philippines, still has a long way to go and currently at its infancy stage before becoming a distinguished program or a course that will be embedded in the academic curricula or be fully recognized by businesses and industries from both national and local levels. The study can be further enhanced to include the level of commitment and motivation of students to such concepts.
\end{abstract}

Keywords: sustainability accounting and reporting; sustainable enterprise; green accounting; sustainability; triple bottom line

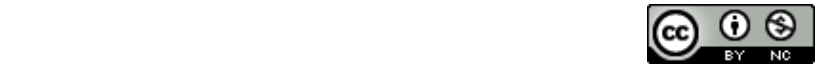

This is an open access article under the CC-BY-NC license

\section{INTRODUCTION}

Sustainability have been introduced in various disciplines of engineering and architecture. In Pujol and Tomás (2020), the concepts of sustainability and sustainable development introduced among robotic engineering degree students by reflecting about the impact of robotic engineering to the planet through designing an environmentally friendly robot that integrates the social, environmental and economic aspects. In Shields, Verga and Blengini (2014), incorporating sustainability into mining and petroleum engineering education can also be achieved through distance education a way to education practicing engineers about sustainability concepts. In Sanganyado and Nkomo (2018), e-learning activities are perfect venues of sustainability concepts and practices among engineering and chemical education students. In Gucyeter (2016), architecture students must be exposed to various sustainability approaches that establishes a balanced comprehension between creativity and integration of sustainability approaches.

While most of the sustainability studies focused are on areas of engineering and architecture, Sustainability in business disciplines, particularly sustainability accounting and reporting, are concepts that are needed to be introduced among people nowadays, most especially to business students.

Corresponding author

Dr. Arnold V.Salcedo, CPA, DBM, asalcedo@hau.edu.ph; Shane S. Salcedo, CPA, ssalcedo@hau.edu.ph 
Journal of Governance Risk Management Compliance and Sustainability (JGRCS), Vol. 1 (1), 76-90

Towards a Sustainable Future: Promoting Sustainability, Sustainability Accounting and Reporting among

Future Professional Accountants

Dr. Arnold V. Salcedo, CPA, DBM, Shane S. Salcedo, CPA

specifically, accountancy students, with the belief that the students today, will be the business leaders of tomorrow. Introducing the basic concepts from the diverse definitions of sustainability, however, remain as a challenge, while capturing the student's interest is another.

According to Index Mundi (2016), about 16.16\%, estimating at around 1.18 billion of the 7.323 billion world population account for people belonging to the 15- to 24-year-old age group. Out of the 102 million Filipinos, 19.17\% fall between the 15-to 24-year old age group or nearly 20 million, which remains significant. Central Intelligence Agency [CIA] (2016) also presents the Philippines' literacy rate of $96.30 \%$ age 15 and over can read and write. This segment of the population can be tapped in increasing sustainability awareness and understanding among people. In Martens and Carvalho (2016), firms are concerned about sustainability in project management; the only challenge is there exists a gap between the perception of importance and the actual use in practice of sustainability . Particularly in public sector firms in which are more concerned about the social dimension compared to others.

McKenna and Biloslavo (2011) emphasized the role of business education and it must be reoriented to include economic sustainability as the core while economic sustainability as the one of its components. Through the development of the intellectual aspects, affective and moral virtues, business students are able to develop a sense of wisdom or intelligence. This practical sense of wisdom can become the basis of the proposed curriculum. Hence, accounting, which translates language of business in layman's terms, must also be part of sustainability.

Filling up this gap can be first addressed through building awareness and education of future sustainability professionals. United Nations Educational, Scientific and Cultural Organization [UNESCO] (2017), emphasizes on this need:

"Education and awareness-raising enable informed decision-making, play an essential role in increasing adaptation and mitigation capacities of communities, and empower women and men to adopt sustainable lifestyles."

Building the understanding, specifically among college students will help introduce and allow to delineate the concept of sustainability from other related concepts which has broader or narrower scope, such as corporate social responsibility, sustainable development, corporate citizenship and conscious capitalism. This can also help spark the interest of students which may promise to pursue careers in business areas that promote sustainability.

The purpose of this study therefore is to build understanding, by introducing the concepts of sustainability and sustainability accounting and reporting, through a selected audiovisual presentation and determine the level of interest, particularly in the area of sustainability accounting and reporting, among accountancy students of Holy Angel University as future proponents of this advocacy. This attempts to determine which areas sparked their interest, in which of the current subjects such concepts can be introduced and what activities can be used to promote and build awareness among students.

In addition, the study aims to answer the following questions:

1. What is the current level of awareness on sustainability accounting and reporting among accountancy students before introducing such concepts to them?

2. What is the current level of interest on sustainability accounting and reporting among accountancy students after introducing such concepts to them?

3. In what areas the concept of sustainability accounting and reporting impacts the most according to accountancy students?

4. In which subject, according to the accountancy students, sustainability accounting and reporting maybe incorporated based on the current curriculum? 
Journal of Governance Risk Management Compliance and Sustainability (JGRCS), Vol. 1 (1), 76-90

Towards a Sustainable Future: Promoting Sustainability, Sustainability Accounting and Reporting among

Future Professional Accountants

Dr. Arnold V. Salcedo, CPA, DBM, Shane S. Salcedo, CPA

5. What are the recommendations for improvement in order that sustainability accounting and reporting would increase the interest among accountancy students?

The main stakeholders who will benefit from this study are the students, because this research serves as a gate way on how basic concepts of sustainability accounting and reporting will increase their interest and hopefully will influence their decisions on deciding on business issues involving sustainability in the future. Schools, colleges and universities with Accountancy programs can learn from this research as this may serve as a starting point and a gauge to introduce the program, concepts and practices on sustainability accounting and reporting. The academicians may also find ways on how to incorporate this in the current Accountancy program and may become one of the courses being offered in the curriculum, giving an option to revise their syllabi. Faculty members are also given a chance to incorporate in their current teachings, the ideas of sustainability accounting and reporting since students are considered the most salient stakeholder may have the option to include this as a future topic for discussion.

Government agencies such as Department of Education and Commission on Higher Education may also issue a CHED Memorandum Order to add sustainability accounting and reporting as part of the Accountancy curriculum. Accountancy regulating bodies may also push for sustainability accounting and reporting in the near future and adopt certain standards that will account for activities that will consider not only the economic, but also the social and environmental impacts of businesses. Future researchers may also use this study as a reference in their future studies. This may serve as a baseline that will help accountancy and future accounting professionals about sustainability accounting and reporting.

\section{LITERATURE REVIEW}

\section{Sustainability}

Students must be given a gist of what sustainability by translating it into a layman's terms and key words which may be derived according of the World Commission on Environment and Development [WCED] (1987) on sustainability, which is the ability to meet the present needs without compromising the ability of the future generations to meet their needs without permanently damaging, altering or depleting the natural environment, ecosystems, species or natural resources.

The three pillars consisting of the key words: economic, social and environmental may increase the interest if shared among accountancy students. By recalling the main thrust of the triple bottom line, puts consideration on the environmental, social and economic impacts within the organization and such impacts could either be positive or negative with the goal to maximize prosperity, planet and people. University of Alberta (2012), defined the triple bottom line using the following:

"Environmental sustainability means ecological integrity is maintained, all of earth's environmental systems are kept in balance while natural resources within them are consumed by humans at a rate where they are able to replenish themselves.

Economic sustainability is where human communities across the globe are able to maintain their independence and have access to the resources that they require, financial and other, to meet their needs. While economic systems are intact and activities are available to everyone, such as secure sources of livelihood.

And social sustainability pertains to the universal human rights and basic necessities are attainable by all people, who have access to enough resources in order to keep their families and communities healthy and secure. Healthy communities have just leaders who ensure personal, labor and cultural rights are respected, and all people are protected from discrimination". 
Journal of Governance Risk Management Compliance and Sustainability (JGRCS), Vol. 1 (1), 76-90

Towards a Sustainable Future: Promoting Sustainability, Sustainability Accounting and Reporting among

Future Professional Accountants

Dr. Arnold V. Salcedo, CPA, DBM, Shane S. Salcedo, CPA

Accountancy students must also be briefed with the difference between sustainability accounting and sustainability reporting such that, on one hand, sustainability accounting as defined by Constructing Excellence (2004), provides a useful tool in identifying, evaluating and managing the social and environmental risks through the identification of efficient resources and cost savings that will link improvements between financial opportunities and environmental issues. Bench marking of performance and identification of best practices are additional services to be offered to businesses.

On the other hand, sustainability reporting according to Boston College (2004) deals with how organizations disclose and communicate environmental, social and economic objectives of an organization. Some of the benefits of sustainability reporting is to building consumer confidence, improving risk management and encouraging innovation.

Topics of interest may also include the Global Reporting Initiative [GRI] (2017) serving as a reporting guideline on sustainability. Using the framework of reporting allows organization to have the opportunity to take hard look on their daily activities and take into account the economic, social and environmental categories. To enumerate, some of the disclosures required are strategy and analysis, organizational profile, identification of material aspects and boundaries, stakeholder engagement, governance, ethics and integrity. Sustainability reporting is also a key in communicating performances on sustainability, which includes the positive or negative impacts.

Informing students of a professional organization for accountancy and its role in sustainability accounting particularly the role of Certified Public Accountants, businesses, industries and governments in sustainability according to American Institute of Certified Public Accountants [AICPA] (2017), may provide current trends in sustainability practices. The CPA role is the provision of services that specifically relates to creating sustainable strategies, assistance in the preparation of sustainability accounting and reporting reports, and assurance. While businesses, industries and the governments are expected to perform an integrative role in helping organizations create value. This can be achieved by forming links with organizations strategic objectives with sustainability, evaluating opportunities and threats and provide assistance in measuring, accounting and reporting sustainability issues.

\section{Sustainability Accounting}

Students may also be reminded of the benefits of maintaining sustainability accounts based on Constructing Excellence (2004) also enumerates the benefits which can be taught to students. One of which is the sustainability report's ability to bridge financial benefits with expenditures through the collection environmental and social information. Sustainable reports can also present how environmental and social external costs can be managed and reduced over time as a commitment to sustainability. Sustainability accounting and reporting may highlight the risks associated with social and environmental dimensions that is associated to financial performance. Another benefit derived from is the ability to map stakeholder relationships, risks and benefits which later on encourages partnerships between stakeholders and organizations.

Another interesting concept that maybe introduced to students is the concept of true cost accounting, which according to Gayeton (2017) is an accounting that includes the cost of negative externalities and accounts for environmental, social and economic costs. External costs as mentioned by Gayeton (2014) are costs or benefits that are forgone by giving up an activity or transaction. True cost accounting also will require time, will power and support and identifies loopholes, losses and risks that will offset cost with benefits. True cost accounting also accounts for the true net income, after all true costs are considered. 
Journal of Governance Risk Management Compliance and Sustainability (JGRCS), Vol. 1 (1), 76-90

Towards a Sustainable Future: Promoting Sustainability, Sustainability Accounting and Reporting among Future Professional Accountants

Dr. Arnold V. Salcedo, CPA, DBM, Shane S. Salcedo, CPA

One of the related studies in sustainability accounting and reporting is with Azapagic, Perdan and Shallcross (2005) that talks about the role of engineering education for sustainable development specifically on how sustainability can be integrated into the curriculum. The study focused in measuring the level of background the engineering students have in sustainable developments with the use of the survey. Determining the knowledge gaps and determining the best approach to educate engineering students about sustainable development were the objects. Based on the results, the level of knowledge, overall, is not satisfactory, which proved that a significant knowledge gap exists.

Characterizing the understanding of undergraduate students about sustainability was done by Carew and Michell (2003) using the structured learning outcomes taxonomy. Using a theoretical synthesis of literature, understanding and empirical investigations regarding sustainability, revealed that students had different variations with the way engineering students understood sustainability.

Sanchez (2016) attempted to document the effects of sustainability and corporate social responsibility in an accounting by introducing the concept by presenting a video and an exercise on a Global Reporting Initiative of Starbucks among Accountancy students of Rider University in spring of 2013, and later on measured the effects of presentation and exercise using survey. The accountancy students' understanding on corporate social responsibility and sustainability accounting and reporting increased after the video presentation.

An interesting study that is close to sustainability accounting is environmental accounting. As defined by Fleishman and Schuele (2006), environmental accounting is a tool for managerial accounting used in reporting and decision making. Businesses are required to define environmental costs that the organization incurs to manufacture goods or provide services. These costs must be incorporated in the annual reports, corporate sustainability reports, corporate social responsibility reports and other related reports.

The research framework of the study as depicted in Figure 1, is focused on developing awareness of the concepts of sustainability and sustainability accounting and reporting. The inputs of the study are the descriptive responses of participants of the study who will be viewing the audio-visual presentation, answering a case activity on true cost accounting and listening to a Global Reporting Initiative sample report presentation. After which, the selected participants will undergo a pre-test and post-test by answering survey before and after the activities. Mean rating, frequency distribution and analysis of variance will be used to analyze the results. The expected output is the assessed level of understanding on sustainability accounting and reporting from which the inferences and recommendations will be derived.

The hypothesis that was developed from this study may test whether there is significant difference on the level of understanding before and after the activities have been provided. Thus,

Ho 1: There is no significant difference in the level of awareness of the respondents before and after the sustainability concepts were introduced to them.

Ha 1: There is a significant difference in the level of awareness of the respondents before and after the sustainability concepts were introduced to them. A priori 


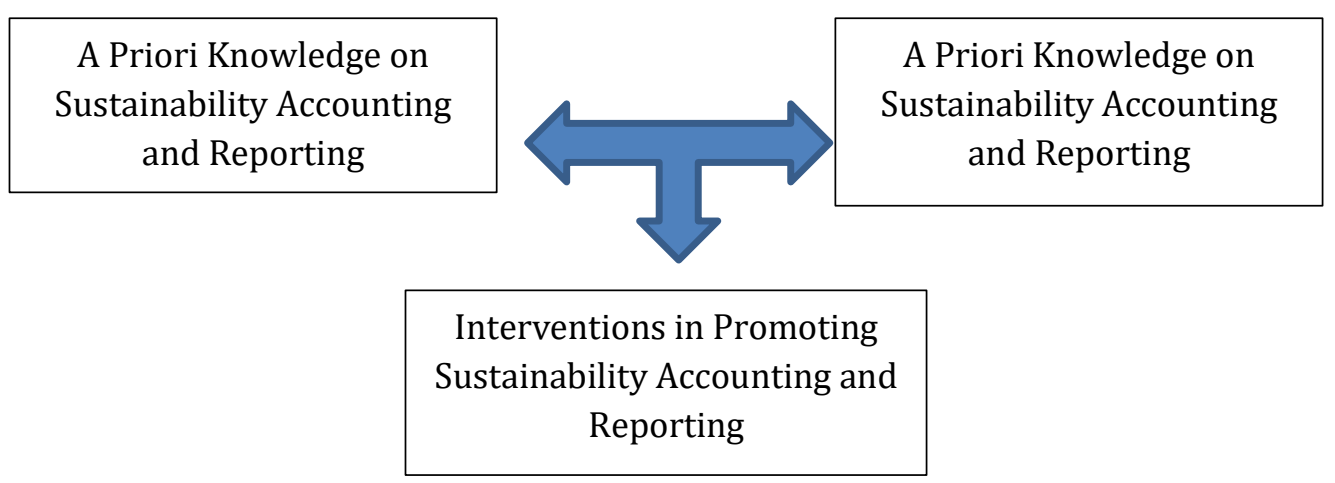

Figure 1 Research Framework

The study was limited in discussing building concepts of sustainability particularly the triple bottom line business model, in order to stimulate understanding. The concept of true cost accounting will be the sole focus for sustainability accounting and one sample of Global Reporting Initiative report was presented. The participants of the study are the FifthYear accountancy students of Holy Angel University as of the First Semester for the Academic Year 2017-2018. The three activities lasted for one hour with twenty minutes time allotted for each activity.

\section{RESEARCH METHOD}

\section{Research Design}

The research is qualitative and quantitative in terms of type and descriptive in design because the study focuses on the generating basic attributes of the participants of the study such as level of awareness or interest of the participants at a given period of time. In order to fully understand, statistical techniques were used in the study. The unit of analysis of the study are individuals since and involved the participation of students as the subject of the study. The point of focus of the study are orientations measured through the level of interest and awareness on sustainability accounting and reporting. The study is cross-sectional since the study is for a given period of time.

The research design is considered as experimental particularly social science experiment, because interventions were made to modify the level of interest or awareness of the study, which tried to change the behavior of the participants (Mendoza, 2012). A pre-test and post-test survey were provided among the participants of the study to explain the difference in the level of awareness or interest of the participant. According to Mendoza (2012), it is possible to conduct experiment with all one group by providing all treatments to all subjects, leaving one control group only.

\section{Sampling and Participants}

The participants of the study are samples coming from one-hundred twenty-six (126) fifth year Accountancy Students of Holy Angel University who are in their terminal year for the undergraduate and are currently enrolled in the First Semester for the Academic Year 2017-2018. Raosoft software was used to compute for the sample size. The margin of error was set at $5 \%$ having a $95 \%$ level of confidence form the one-hundred twenty-six students given a 50\% response rate. As computed, a ninety-six (96) fifth year accountancy student were the participants of the study because these students have completed all the required management subjects such as strategic management and has a firm grasp of almost the entire core accounting courses compered to their junior year levels. 
Journal of Governance Risk Management Compliance and Sustainability (JGRCS), Vol. 1 (1), 76-90

Towards a Sustainable Future: Promoting Sustainability, Sustainability Accounting and Reporting among

Future Professional Accountants

Dr. Arnold V. Salcedo, CPA, DBM, Shane S. Salcedo, CPA

\section{Data Gathering Instruments}

Self- administered survey closely patterned but a modified version of Sanchez (2016) before and after the intervention activities that showcased the a gist of the concepts of sustainability and sustainability accounting and reporting using the following: a short clip of an audio-visual presentation regarding the (Triple-Bottom line), case activity on true cost accounting (Case of Two Farmers) and sample presentation of the Global Report Initiative on Sustainability (Starbucks' Global Responsibility Report) all for one hour. The first part of the survey would require information on the demographic information of the respondent and the second part of the survey responded to the statements using a four-point likert scale for before and after the interventions were made to the students. The last part of the survey is follow-up questions related to the study in which the participants were free to choose between yes or no questions.

A Cronbach alpha test was run to determine the reliability and validity of the adopted instrumentbased form the responses of the 96 respondents. The instrument with ten (10) statements before the interventions were applied resulted to a Cronbach's Alpha on standardized items of 0.78, which is acceptable and have exceeded the 0.70 standard. The statements after the intervetions were made likewise resulted to a very high internal consistency coefficient (Cronbach's alpha) of the scale was 0.974, indicating a high degree of reliability and validity (Yavuzalap \& Bacivanb, 2019) of the instrument used.

\section{Data Collection Procedures}

This section describes in detail the data-collection procedures. The primary sources of information were the results of the surveys after the series of activities have been implemented. Secondary sources of information quotes came from publications, such sources include comments on, interpretations of, or discussions about the original research conducted abroad. Academic research works using electronic source will be used as a related study.

\section{Data Analysis}

The study was analyzed using statistical tools used on this study include frequency and percentage distribution, mean rating, and analysis of variance. They were used to describe and assess the data gathered by the researchers through the survey questionnaires and interview guide conducted. Since the survey adopted, the survey form was not subjected to reliability test. Frequency and percentage distribution is an arrangement of the values that one or more variables take in a sample. The demographic profile of examinees was used in this process. Mean rating before and after the activities was determined in order to determine the "balance point" in a set of data, it was used to determine the descriptive rating of the responses. This were used to determine the results on the level of awareness after the participants were involved in three different activities.

\section{Ethical Considerations}

The consent of the Dean, Chairperson and Department Coordinator of the Accountancy Program of the School of Business and Accountancy, Holy Angel University in Angeles City, Pampanga, Philippines were obtained for the permission to conduct the study. Permission to partially adopt the survey instrument of Sanchez (2016) was also be obtained through email. Results of the research were used for academic purposes only. 


\section{FINDINGS AND DISCUSSION}

The following tables summarizes the results of the study. Table 1 provides information on the gender profile of the respondents where most of the participants are composed of female students ( $n=68)$ in their terminal year. While Table 2 provides a summary in which Sustainability Accounting and Reporting may be assigned in the current undergraduate curriculum. Good governance $(n=58)$, accountancy research $(n=7)$, management services $(n=6)$ and auditing $(n=10)$ are courses in which topics in sustainability may be incorporated. These may also include discussions of environmental accounting, corporate social responsibility and business ethics. Only a few respondents $(\mathrm{n}=13)$ have considered it as a possible separate course which indicates that Sustainability Accounting and Reporting is not seen as a major course in the undergraduate and may only be a part of the topic for discussion. This may also imply that Sustainability Accounting and Reporting may be pursued in the graduate school.

Table 1. Gender of Participants

\begin{tabular}{|l|c|c|c|c|}
\hline Participants & Frequency & Percent & Valid Percent & Cumulative Percent \\
\hline Male & 28 & 28.9 & 29.2 & 29.2 \\
\hline Female & 68 & 69.1 & 69.8 & 100 \\
\hline Total & 96 & 100 & 100 & \\
\hline
\end{tabular}

Table 2. Suggested Course for Sustainability Accounting and Reporting

\begin{tabular}{|l|c|c|c|c|}
\hline Subject or Course & Frequency & Percent Valid Percent & Cumulative Percent \\
\hline Fundamentals of Accounting & 1 & 1 & 1 & 1 \\
\hline Management Services & 6 & 6.2 & 6.2 & 7.2 \\
\hline Taxation & 1 & 1 & 1 & 8.2 \\
\hline Good Governance & 58 & 59.8 & 59.8 & 68 \\
\hline Financial Accounting & 3 & 3.1 & 3.1 & 71.1 \\
\hline Audit Theory & 4 & 4.1 & 4.1 & 76.3 \\
\hline Audit Problems & 3 & 3.1 & 3.1 & 79.4 \\
\hline Accountancy Research & 7 & 7.2 & 7.2 & 86.6 \\
\hline Separate Subject & 13 & 13.4 & 13.4 & 100 \\
\hline Total & 96 & 100 & 100 & \\
\hline
\end{tabular}

Tables 3 and Table 4 show a significant change in the level of awareness for Accountancy Students when it comes to Sustainability Accounting and Reporting. After the concepts where introduced, there were obvious changes in the responses of the students which increased the current level of interest. This is also measured based on the result shown using the One-Sample T-test $(.050>\operatorname{sig} .000)$ in Table 5 which implies the impact created on both the a priori and posteriori knowledge of the respondents as a result of the three intervention activities done in the study. 
Table 3. Summarized Statements Before Sustainability Activities

\begin{tabular}{|l|l|}
\hline \multicolumn{1}{|c|}{ Statements } & Mean Rating \\
\hline $\begin{array}{l}\text { 1. I am aware of the role of sustainability and sustainability } \\
\text { accounting and reporting in business. }\end{array}$ & $1.50=$ Strongly Disagree \\
\hline 2. I am familiar with the concept of Triple Bottom line. & $1.09=$ Strongly Disagree \\
\hline $\begin{array}{l}\text { 3. I understand that sustainability and sustainability accounting and } \\
\text { reporting in business are important for business leaders. }\end{array}$ & $1.70=$ Strongly Disagree \\
\hline $\begin{array}{l}\text { 4. I believe that sustainability practices will make businesses } \\
\text { profitable in the long run. }\end{array}$ & $2.11=$ Disagree \\
\hline $\begin{array}{l}\text { 5. It is important to have reporting standards in place for } \\
\text { sustainability measures. }\end{array}$ & $2.27=$ Disagree \\
\hline $\begin{array}{l}\text { 6. It is important to have assurance standards in place for } \\
\text { independent accountants on sustainability accounting and reporting. }\end{array}$ & $2.28=$ Disagree \\
\hline \begin{tabular}{l} 
7. I have a background of true cost accounting. \\
\hline $\begin{array}{l}\text { 8. There will be significant growth in the area of sustainability } \\
\text { accounting and reporting }\end{array}$
\end{tabular} & $2.00=$ Disagree \\
\hline $\begin{array}{l}\text { 9. Sustainability in businesses is not a waste of time. } \\
\text { 10. I am aware of the role of independent accountants in } \\
\text { sustainability accounting and reporting. }\end{array}$ & $2.29=$ Disagree \\
\hline
\end{tabular}

Table 4. Summarized Statements After Sustainability Activities

\begin{tabular}{|l|c}
\hline \multicolumn{1}{|c|}{ Statements } & Mean Rating \\
\hline $\begin{array}{l}\text { 1. My understanding of the role of sustainability and sustainability } \\
\text { accounting and reporting in business increased ffter the activities. }\end{array}$ & $3.44=$ Agree \\
\hline $\begin{array}{l}\text { 2. My understanding of the concept of Triple Bottom line has } \\
\text { increased after the activities. }\end{array}$ & $3.41=$ Agree \\
\hline $\begin{array}{l}\text { 3. I understand that sustainability and sustainability accounting and } \\
\text { reporting in business are important for business leaders. }\end{array}$ & $3.58=$ Agree \\
\hline $\begin{array}{l}\text { 4. I believe that sustainability practices will make businesses } \\
\text { profitable in the long run. }\end{array}$ & $3.53=$ Agree \\
\hline $\begin{array}{l}\text { 5. It is important to have reporting standards in place for } \\
\text { sustainability measures. }\end{array}$ & $3.55=$ Agree \\
\hline $\begin{array}{l}\text { 6. It is important to have assurance standards in place for } \\
\text { independent accountants on sustainability accounting and } \\
\text { reporting. }\end{array}$ & \\
\hline 7. I have now a background of true cost accounting. & $3.46=$ Agree \\
\hline $\begin{array}{l}\text { 8. There will be significant growth in the area of sustainability } \\
\text { accounting and reporting }\end{array}$ & $3.51=$ Agree \\
\hline 9. Sustainability in businesses is not a waste of time. & $3.41=$ Agree \\
\hline $\begin{array}{l}\text { 10. I am now aware of the role of independent accountants in } \\
\text { sustainability accounting and reporting. }\end{array}$ & $3.68=$ Agree \\
\hline
\end{tabular}


Table 5. One-Sample Test

\begin{tabular}{ccccccc} 
Timing & t & df & $\begin{array}{c}\text { Sig. (2- } \\
\text { tailed) }\end{array}$ & $\begin{array}{c}\text { Mean } \\
\text { Difference }\end{array}$ & $\begin{array}{c}\text { 95\% Confidence Interval } \\
\text { of the Difference }\end{array}$ \\
\hline & & & & & Lower & Upper \\
Before & 28.467 & 96 & 0.000 & 1.89 & 1.76 & 2.02 \\
After & 78.855 & 96 & 0.000 & 3.482 & 3.39 & 3.57 \\
\hline
\end{tabular}

Further results of the study are shown from Table 6 to Table 10 showing an increased level of awareness and interest among students after the sustainability concepts have been introduce to them. Mostly, if not all of the student believes that there is a need to understand sustainability accounting and reporting as seen on Table 6. In troducing such concepts to the undergraduate level through captured their interest and provided opportunities among institutions to look into their curricula in order to address the results of these studies. Academic institutions may also initiate the proliferation of awareness of sustainability, sustainability accounting and sustainability reporting now that a possible market (i.e., undergraduate students) are somehow willing to accept these new concepts. Faculty members and administrators, composed of professional accountants, may respond to these results through by setting meeting initiatives with academic regulators, professional and business organizations to fill this gap to allow sustainability concepts reach the realms of academic institutions.

Table 6. Summary of Statement "I believe college students like me need to understand sustainability accounting and reporting."

\begin{tabular}{|l|c|c|c|c|}
\hline Yes or No & Frequency & Percent & $\begin{array}{c}\text { Valid } \\
\text { Percent }\end{array}$ & \multicolumn{1}{c|}{ Cumulative Percent } \\
\hline Yes & 96 & 100.0 & 100.0 & 100.0 \\
\hline No & 0 & 0.0 & 0.0 & 100.0 \\
\hline Total & 96 & 100.0 & 100.0 & 0.0 \\
\hline
\end{tabular}

There is is a growing interest of students to enroll in the programs that put emphasis on sustainability which is Leadership in Sustainable Enterprise or Green MBA as presented on Table 7. In Higher Education (2021), offering of Green MBA is very important because having environmentally and socially sustainable management policies are now becoming more important for both large and small businesses establishments. Such programs help to develop sustainable leaders who can look beyond immediate and short-term profits to a larger context, such as setting strategies ensuring the delivery of results that meet the triple bottom line model of economic, social and environmental performance (Russel Reynolds Associates, 2015).

Table 7. Summary of Statement "I am interested to enroll in graduate degree programs that have emphasis on sustainability such as Green MBA."

\begin{tabular}{|l|c|c|c|c|}
\hline Yes or No & Frequency & Percent & Valid Percent & Cumulative Percent \\
\hline Yes & 54 & 55.7 & 56.3 & 56.3 \\
\hline
\end{tabular}


Journal of Governance Risk Management Compliance and Sustainability (JGRCS), Vol. 1 (1), 76-90

Towards a Sustainable Future: Promoting Sustainability, Sustainability Accounting and Reporting among

Future Professional Accountants

Dr. Arnold V. Salcedo, CPA, DBM, Shane S. Salcedo, CPA

\begin{tabular}{|l|c|c|c|c|}
\hline No & 42 & 43.3 & 43.3 & 100.0 \\
\hline Total & 96 & 100.0 & 100.0 & \\
\hline
\end{tabular}

The increased level of understanding in the advocacy of sustainability by simply participating in the provided activities are shown on Table 8. In Niemotko (2017), sustainability accounting and are important areas for future CPAs to become familiar particularly the millennial professionals in order to determine the qualitative value that businesses add to the society today. Companies should not only be responsible for financial data reporting but also to the communities and environment that surround them. Millennials may consider becoming loyal to companies that care and provide qualitative data in addition to quantitative data; thus, sustainability data provides a sense of "personal" connection.

Table 8. Summary of Statement "I somehow now understand the advocacies of sustainability."

\begin{tabular}{|l|c|c|c|c|}
\hline Yes or No & Frequency & Percent & $\begin{array}{c}\text { Valid } \\
\text { Percent }\end{array}$ & Cumulative Percent \\
\hline Yes & 94 & 96.9 & 97.9 & 97.9 \\
\hline No & 2 & 2.1 & 2.1 & 100.0 \\
\hline Total & 96 & 100.0 & 100.0 & \\
\hline
\end{tabular}

Accountancy students see a pressing need to include standards of sustainability looking at Table 9 , considering accounting is the language of business, sustainability accounting and reporting may not only appliable among larger corporations. In Report ASAP (2017), there exists a knowledge gap between best sustainability practices and the reality of sustainability reporting literacy for small and medium enterprises (SMEs) where future professional accountants maybe deployed.

Table 9. Summary of Statement "I think there is a need for developing and adopting standards on sustainability."

\begin{tabular}{|l|c|c|c|c|}
\hline Yes or No & Frequency & Percent & Valid Percent & Cumulative Percent \\
\hline Yes & 95 & 97.9 & 97.9 & 97.9 \\
\hline No & 1 & 1.0 & 1.0 & 100.0 \\
\hline Total & 96 & 100.0 & 100.0 & \\
\hline
\end{tabular}

More interesting is how accountancy students see the pressing need to include the standards of sustainability as reported on Table 10. Since consumers interest in sustainability is now gradually increasing consumption factors are now extending beyond the environment, including affordable food, fair wages and humanely raised animals (Sosland Publishing Company, 2021). Sustainability accounting standards standards must now encompass social, economic and environmental dimensions.

Table 10. Summary of Statement "I would like to learn more about sustainability accounting and reporting."

\begin{tabular}{|l|c|c|c|c|}
\hline Yes or No & Frequency & Percent & Valid Percent & Cumulative Percent \\
\hline Yes & 94 & 96.9 & 97.9 & 97.9 \\
\hline No & 2 & 2.1 & 2.1 & 100.0 \\
\hline
\end{tabular}


Journal of Governance Risk Management Compliance and Sustainability (JGRCS), Vol. 1 (1), 76-90

Towards a Sustainable Future: Promoting Sustainability, Sustainability Accounting and Reporting among

Future Professional Accountants

Dr. Arnold V. Salcedo, CPA, DBM, Shane S. Salcedo, CPA

\begin{tabular}{|l|l|l|l|l|}
\hline Total & 96 & 100.0 & 100.0 & \\
\hline
\end{tabular}

\section{CONCLUSION \& FURTHER RESEARCH}

Sustainability accounting and reporting is a concept that needs to be raised in terms of level of awareness among the students at this time and age. This can be inferred from the responses based on the activities participated by students. The level of interest goes to show that introducing concepts of sustainability, sustainability accounting and sustainability reporting among students, spark their current level of interest. These concepts can be introduced at an earlier stage because currently, these courses are being offered to students in the graduate school or to those who are taking graduate degrees or specialization course, where the time and attention required to finishing the degree would require a completion of a capstone project. In order to advance the concepts of sustainability accounting and reporting, it is crucial that these concepts are also included in the course syllabus of the students currently taking up an accounting degree or related course in business. In Aznar., Martinez-Agut, Palacios, Pinero, and Ull (2011) even if there is a widespread support for introducing sustainability across the university's curricula; there will still be significant differences across various disciplines including how they relate to departmental perceptions, most especially when it comes to interpretations and performance of sustainability-related teaching. Therefore, standards for concepts in different disciplines must be established.

A challenge to presenting such concept is the incorporating and relating these to practice subjects such auditing and taxation and how professors would include them in classroom discussions. The level of awareness must reach a higher level that it will reach the regulatory bodies (i.e. Commission on Higher Education) of academic institutions in order to initiate standards and promulgate laws in the advancement of sustainability accounting and reporting also remains imperative. These business courses must be developed around the principles of sustainability demonstrating the link between competitive actions and outcomes (Marshall and Harry, 2005).

As a conclusion, the sustainability accounting and reporting in the Philippines, still has a long way to go and still, at its infancy stage when it comes to sustainability and to be recognized with full distinction, a program or a course that will be embedded and recognized among institutions and businesses. The stronghold that will continue to uplift these concepts are coming from the future generations who are ready to accept changes in the business models into landscapes and implement these changes with the businesses they will lead in the future.

\section{Unique Contributions, Originality, Value and Managerial Implications}

This study contributes to the body of knowledge of accountancy since the perspective of accountancy of the students have been the focused of the study. The study is original in a sense that three unique activities were incorporated to introduce the concepts among accountancy students, through selected audio video presentations. The originality and value of this study lies on its participants as most studies on introducing sustainability concepts involve mostly engineering, architectural, or business students but not accountancy students.

Some implications of the study would include looking into the various learning styles and approaches in teaching sustainability, sustainability accounting and reporting. In Mac Vaughn and Norton (2012), introducing sustainability into business education using active learning approaches allow learners to move away from dependence on educators and towards a personal responsibility approach. Using a 
global "global" sense approach instead of the "business as usual" applications, may help address the legitimacy and practicability in introducing sustainability education in business degree programs. For example, introducing the creation of standards in the Sustainability Accounting Standards Board [SASB] (2018), will enable businesses in the identification, management and communication of financiallymaterial sustainable information for investors. With 77 globally applicable industry specific standards set the financially material sustainability topics along with the activity metrics which will serve as the unit of measure to properly account for every business undertaking. The standards, likewise, provide the necessary guidelines and disclosure requirements.

Another implication is the level of commitment, participation and motivation which could be another focus of study to be compared with the results of students of other disciplines. In Pujol and Tomas, (2020) high level of commitment was demonstrated by students with respect to sustainability, however, was coupled with lack of active participation and awareness as to their impact of future robotic engineers was also revealed.

As a recommendation, the following steps may be taken to build the level of awareness on sustainability accounting and reporting:

1. Conduct of seminars and fora among students and faculty members in the Academe to initially become aware and be informed of the concepts of sustainability, sustainability accounting and sustainability reporting.

2. Review of the current curricula and syllabi of schools, colleges and universities and position the course sustainability, sustainability accounting and sustainability reporting in the suitable subject such as Good Governance or Auditing Theory.

3. Expose academic institutions to capstone projects on sustainability, these to include corporate social responsibility and environmental programs of businesses and organizations that makes it sustainable.

These are some of the steps on how sustainability accounting and reporting can be further advanced as course or program among business and accountancy students. And these will serve as a springboard among students who will be molded into forming and managing businesses that put emphasis not only for economic gains, but also consider people and the environment towards a sustainable future.

\section{Research Limitations and Future Research Directions}

This study is limited to accountancy students who are on their terminal year in a university in the Philippines. The learning styles, behaviour, levels of commitment, acceptance, participation and motivation are not included in the study. Getting the perspectives of faculty members who will be teaching the sustainability concepts and those engaged in the public practice of accountancy, can be another future direction of the study. Most importantly, are the salient stakeholders are business owners who have not yet reached the level of full awareness, particularly Micro, Small and Medium Enterprises in which introducing the sustainability concepts can also be prioritized.

\section{ACKNOWLEDGEMENT}

We extend our gratitude to those who supported our study, from the school administrators to faculty members of the School of Business and Accountancy, Holy Angel University, Angeles City in Pampanga, Philippines. Our sincerest thank you to the Fifth Year Students BS Accountancy for the School 
Year 2017-2018 (Batch Vicimus) who are now professional accountants today and became participants of our study. Lastly, we thank our families Salcedo and Sigua who supported us on this endeavor.

\section{REFERENCES}

American Institute of Certified Public Accountants [AICPA] (2017). Central Intelligence Agency (2016). World Factbook.. Retrieved from: https://www.cia.gov/library/publications/the-worldfactbook/fields/2103.html

Azapagic, A., Perdan, S., \& Shallcross, D. (2005). How much do engineering students know about sustainable development? The findings of an international survey and possible implications for the engineering curriculum. European Journal of Engineering Education, $\quad 30(1), 1-19$.

Aznar M. P., Martinez-Agut, M. P., Palacios, B., Pinero, A., \& Ull, M. A. (2011). Introducing sustainability into university curricula: an indicator and baseline survey of the views of university teachers at the University of Valencia. Environmental Education Research, 17(2), 145-166.

Boston College (2014). Center for Corporate Citizenship, Sustainability Reporting. Retrieved from: http://ccc.bc.edu/sustainability-reporting.html

Central Intelligence Agency [CIA] (2016). Philippines Literacy Rate. https://www.cia.gov/library/publications/the-world-factbook/fields/370.html

Carew, A. L., \& Mitchell, C. A. (2002). Characterizing undergraduate engineering students' understanding of sustainability. European journal of engineering education, 27(4), 349-361.

Constructing Excellence (2004). Benefits of Sustainable Development. Retrieved from: http://constructingexcellence.org.uk/resources/introduction-to-sustainable-construction/

Fleischman, Richard K. and Karen Schuele, 2006, "Green Accounting: A Primer," Journal of Accounting Education, 24(1).

Gayeton, D. (2017). Food Terms. True Cost Accounting. Retrieved from: http://www.pbs.org/food/features/lexicon-of-sustainability-true-cost-accounting-the-real- cost-ofcheap-food/

Global Reporting Initiative (2017). About Sustainability Reporting. What is Sustainability Reporting? Retrieved from: https://www.globalreporting.org/information/sustainabilityreporting/Pages/reporting-benefits.aspx

Gucyeter, B. (2016). The place of sustainability in architectural education: discussion and suggestions. Athens Journal of Architecture, 2(3), 237-256.

Higher Education (2021). What is Green MBA? https://www.bestcollegereviews.org/faq/what-isa-green-mba

Index Mundi (2016). World Populiation. https://www.indexmundi.com/

MacVaugh, J., \& Norton, M. (2012). Introducing sustainability into business education contexts using active learning. International Journal of Sustainability in Higher Education.

Marshall, R. S., \& Harry, S. P. (2005). Introducing a new business course:"Global business and sustainability". International Journal of Sustainability in Higher Education.

Martens, M. L., \& Carvalho, M. M. (2016). The challenge of introducing sustainability into project management function: multiple-case studies. Journal of Cleaner Production, 117, $\quad$ 29-40.

Mendoza, R. (2012). Accountancy Research Theory and Practice. Classification of Research Design. ISBN: 978-971-0165-08-7 
Journal of Governance Risk Management Compliance and Sustainability (JGRCS), Vol. 1 (1), 76-90

Towards a Sustainable Future: Promoting Sustainability, Sustainability Accounting and Reporting among

McKenna, B. and Roberto B. (2011). "Human Flourishing as a Foundation for a New Sustainability Oriented Business School Curriculum: Open Questions and Possible Answers," Journal ofManagement \& Organization, 17(5).

Niemotko, T. J. (2017). The importance of sustainability accounting and reporting in assessing a firm: A student's perspective. https://www.accountingtoday.com/opinion/the-importance-ofsustainability-accounting-and-reporting-assessing-a-firm-a-students-perspective

Pujol, F. A., \& Tomás, D. (2020). Introducing Sustainability in a Robotic Engineering Degree: A Case Study. Sustainability, 12(14), 5574.

Report ASAP Project (2018). Adoption of Sustainable Accounting Practices for Reporting Transnational Phase: Development of the Final Study Report https://report-asapproject.eu/sites/reportasap.eu/files/Report-ASAP_I01_A3_final.pdf

Russel Reynolds Associates (2015). Sustainable leadership:Talent requirements for sustainable enterprises.https://www.russellreynolds.com/en/Insights/thoughtleadership/Documents/russell_reynolds_sustainable_leadership.pdf

Sanchez, H.M. (2016). Introducing the Concepts of Sustainability and Corporate Social Responsibility to Accounting Students. https://papers.ssrn.com/sol3/papers.cfm?abstract_id=2731222

Sanganyado, E., \& Nkomo, S. (2018). Incorporating sustainability into engineering and chemical education using E-Learning. Education Sciences, 8(2), 39.

Shields, D., Verga, F., \& Blengini, G. A. (2014). Incorporating sustainability in engineering education. International Journal of Sustainability in Higher Education.

Sosland Publishing (2021). Consumer interest in sustainability is still growing. https://www.foodbusinessnews.net/articles/17988-consumer-interest-in-sustainability-is-still-growing

Sustainability Accounting Standards Board [SASB] (2018). Standards Overview. Contents of Standards. https://www.sasb.org/standards-overview/

United Nations Educational, Scientific and Cultural Organization [UNESCO] (2017). Climate Change Education and Awareness, Education for Sustainable Development. Retrieved from: http://en.unesco.org/themes/addressing-climate-change/climate- change-education-and-awareness

University of Alberta (2016). Our Definition of Sustainability. Sustain SU. The Student Sustainability Servic. https://www.su.ualberta.ca

World Commission on Environment and Development [WCED](1987). Brundtland

Commission. Retrieved from: http://www.un-documents.net/our-common-future.pdf

Yavuzalp, N., \& Bahcivan, E. (2020). The online learning self-efficacy scale: its adaptation into Turkish and interpretation according to various variables. Turkish Online Journal of Distance Education, 21(1), 31-44. 